\title{
ROLE OF RESOURCE - TECHNOLOGICAL MECHANISM IN DEVELOPMENT OF ELECTORAL COMMUNICATION IN UKRAINE
}

\author{
Maksym Mikhailov \\ Postgraduate Student at the Department of Parliamentary and Political Management, \\ National Academy for Public Administration under the President of Ukraine, Ukraine \\ e-mail: myhailov.m@sl.net.ua; orcid.org/0000-0001-7829-3470
}

\section{Summary}

Digital transformations taking place in Ukraine require public authorities to be effective and active position of the civil society. In this case, joint activities become the basis for implementation of respective public policy on central, regional and local levels.

Mechanisms of digital democracy should accelerate introduction of electronic elections in Ukraine, improve quality of electoral communication between voters and the candidates for public office. Public institutions also strengthen existing and operating digital technologies in public authorities at the same time contributing to formation of innovative technologies, both for the state and for separate settlements. In his article, the author outlines existing trends in this area of activity in order to consolidate efforts to improve the quality of electoral communication and introduce electronic elections in Ukraine.

It is new digital tools, communication services and open platforms that can provide new innovative solutions to increase political participation and involve citizens into the electoral processes, helping to increase level of trust, transparency and accountability within the democratic system.

The author, referring to the European Parliament Resolution of 16 March 2017 on E-democracy in the EU, outlining future potential of digital democracy, in particular the use of digital communication as its key feature, stating that many examples of national, regional and local digital participation can serve as examples of how digital (information and communication) technologies are used in E-democracy and encourage further development of such practices at the national and local levels in Ukraine

Keywords: e-democracy, digital technologies, electoral communication, electoral process, national and local levels, innovative solutions, political participation, participatory democracy.

\section{DOI: https://doi.org/10.23856/4220}

\section{Introduction}

In the European Parliament resolution of 16 March 2017 on e-democracy in the EU (European Parliament resolution of 16 March 2017 on e-democracy in the European Union: potential and challenges (2016/2008 (INI)) (Buchyn M.,2015: 48-57) the potential and challenges are identified, it is also noted that the tools of digital democracy can contribute to the active position of citizens through enhanced participation, transparency and accountability in decision-making processes; supporting mechanisms of democratic oversight in order to provide citizens with more opportunities to express their will in political life.

In accordance with the "Guidelines for Public Participation in Political Decision-Making" adopted by the Committee of Ministers on 27 September 2017 at the 1295 th Meeting of the 
Ministers' Deputies, the Council of Europe encourages member states to use expert information to create a culture of effective electronic systems based on respect for human rights, democracy and the rule of law (Guidelines for public participation in the political decision-making process, 2017: 12).

Considering the given types of citizen participation, we observe that dissemination of information can take place both in paper form (offline) and online, and participation process can be accompanied by resource-technological mechanism of information and communication support of the election process, which should serve as basis to create instructions, materials and other online and offline tools, conducting series of trainings for civil society in this field (Vyryn F., 2009:124).

It is crucial that we start designing transition to strategic change, at least 5 years in advance, because if you implement activities without anticipating technological challenges and opportunities, as well as without taking into account trends related to development of similar tools abroad, it may lead to inefficiency of such services right after their introduction.

That is why formation of local, regional and national policies for transition from electronic to digital democracy in the electoral process requires a deeper analysis of trends and challenges for the tools, technological environment, and developmental directions of participatory and deliberative democracies in Ukraine.

\section{Prerequisites for implementation of resource-technological mechanism of electoral communication}

The scientific works of W. Beckers, S. Best and B. Krueger, S. Carvel, M. Dickin, J. Cooper and K. Paskalev, J. Ravetz and D. Babitski outline development of technological infrastructure, that led to the launch of new projects aimed at the use of ICT potential.

Electoral technologies as elements of electoral process are studied by N. Barna, V. Bebyk, D. Vydrin, O. Vyshnyak, V. Kolyadenko, L. Kochubey, N. Likarchuk, V. Lugovska, A. Nalyotov, O. Petrov, V. Poltorak, G. Pocheptsov, O. Prikhodko, R. Starovoitenko, O. Khromets, E. Yurchenko.

I. Burkut, V. Burdyak, M. Buchyn, M. Kolesnikov, A. Kruglashov, O. Litvinenko, V. Marchuk, A. Romanyuk, L. Skochylias, and Y. Yakymenko deal with the peculiarities of the course of electoral processes at the regional level. In the field of digital democracy O. Levchenko, O. Karpenko and others (Karpenko O., Levchenko O., Sakalosh S., 2019:124).

Formation of regional and local bylaws depends not only on approaches and decisions, but also on availability of research in the areas of electoral processes, digital democracy, participation. In fact, national legal framework should be the basis for local and regional decision-making, as the key element is democratic decision-making process, which will be ensured by coherence of policies at different levels forming management decisions in the field of digitalization (Kuibida V. S., 2018: 2-8).

We believe that the formation of a unified approach and standardization of development of digital democracy at the country, region and community levels will lead to several socio-economic effects. In particular, it will reduce the cost of interoperability of tools and integration with public digital resources, including registers, systems, databases, as well as identification systems, etc. An integrated approach will allow high-quality use of open data resources and create additional products based on them. Moreover, it will reduce the cost of training, promoting and developing skills in the use of products, systems and results.

Integration between digital democracy services will increase their transparency, publicity of electoral communication, accessibility of electronic elections in Ukraine. However, this 
is only possible with a harmonized legal framework in the field of digital governance and common approaches and standards to formation of appropriate instruments in electoral legislation (Levchenko O., 2018: 72-73).

Over time, unification of standards and approaches to functioning of digital democracy instruments can promote integration with international and individual national products of other countries in the field of digital democracy.

Digital transformation in Ukraine at the local level has been active since 2017 and has many positive achievements, both in terms of individual local solutions and those that interact with national products and tools, such as e-petitions. Further transformation of e-democracy into digital one requires adoption of systemic legal documents that would set key priorities, as well as introduction of sustainable institutions and processes to deal with implementation of the latest digital tools. Digital democracy, as opposed to e-democracy, at the local level should have a broader practical dimension in order to increase citizens' trust in government, especially in the inter-election period at the mayor, city council, individual deputies and other institutions of amalgamated territorial communities' level (Kuibida V. S., 2018: 4).

Regional or municipal (local) Concepts of digital democracy should become legal acts defining clear mechanisms of digital democracy for citizens, business representatives, in particular start-up companies.

\section{Realization principles of resource-technological mechanism for electoral communication}

Basic trend for transformations of Industry 4.0 is rapid pace of development of digital technologies and their rapid implementation in various fields of society, in particular in the field of state policy for implementation of digital transformations. Therefore, we will define the principles and offer recommendations for development of digitalization concepts at the local level (Chala N.D., 2018: 405-407).

First, is the principle of having groups of experts to follow the trends of digital transformations. Combination (concentration) of trends and technologies in relation to the needs of governance creates conditions for transition from electronic to digital democracy. Today, the toolkit of e-democracy, not promoting involvement and participation of people, is a nominal tool, especially if it is not mandatory for both the government and citizens in managing decisions and interaction process. Therefore, it decreases interest and need to use e-democracy tools.

Second, it is a secure principle for development of digital democracy, which is a must to ensure protection of personal data by the authorities. The Concept of Digital Democracy at the local level must take into account not only the aspect of using technology for the city, but also the interest of residents themselves. It is important to anticipate the use of data safeguards and monitor this process at the local level. The city systems generate a lot of open data, and it is necessary not only to use, but also to take into account private interests, whose security must also be implemented. On the other hand, open data should create new tools for citizens to understand urban processes in order to increase their quality (in particular, logistics, cost, versatility and efficiency of municipal services). For example, a popular digital navigation service in Poland "Jakdojade Warszawa" (https://jakdojade.pl) allows you to manage your travel route, specifying interactive map and schedule of public transport.

Third is the principle of transformation (cognitive component of evolution of transformation), in which e-democracy is transformed into digital democracy (important in development 
of digital democracy tools is the approach in which innovative tools should help citizens understand how government works, how managerial decisions are adopted and what is the best way to streamline administrative processes).

Lack of understanding of the essence, content, value, procedure and duration of management processes leads to populism, that does not require any mechanisms of public administration in general, digital democracy in particular. So effectiveness of digital democracy lies in the quantity and quality of users, as well as the explanation quality for the essence of functioning of tools and processes (responsibility, transparency, competence, etc.) and principles of their delimitation at national, regional and local levels (Adams M., Banerjee A., Bayamlioglu E., 2017: URL).

Fourth, it is the principle of processability which is the formation of integrated digital platforms with a single point of access to content, various services and tools for digital participation, saving time receiving services (receiving specific benefits) of consumers of service activities. The toolkit should promote the level of interaction between services and tools of digital democracy of different territorial communities at the horizontal level, as well as to ensure data exchange between them (it is recommended to develop unified list of tools, unify approaches to implementation, create common development centers for digital services and develop common digital standards) (Chala N.D., 2018: 405-407).

\section{Conceptual approach to the implementation of resource-technological mechanism of electoral communication}

Regional and local Concepts of Digital Democracy cannot solve problems of national scale, but it is worth paying attention to normative documents that are already successfully functioning at the level of Ukraine and outside the country. After all, possibility of integration with them will lead to more effective involvement of citizens in management of decision-making processes.

The development of regional and local Concepts of digital democracy makes it possible to analyze current state of e-democracy and identify priority measures for implementation of digital democracy to improve the mechanisms of information and communication support of the electoral process in Ukraine. Formation of digital democracy policy in electoral process is a new phenomenon in implementation of approaches to citizen participation in electoral communication with the prospect of electronic parliamentary and presidential elections. Such approachhelps to respond quickly to global challenges that exist in society, as well as to form the party's brand, the image of a presidential candidate in accordance with their characteristics. That is why it is important to understand that development of state policy on the use of digital democracy requires consideration of existing level of democracy, trust in government institutions and willingness to cooperate, introduction of new, in particular, resource-technological mechanism of information and communication support of election process in Ukraine (Kuibida V. S., 2018: 5).

In accordance with these problems, the ways and means of solving them through implementation of certain list of tasks and measures, where the main ones were formation of digital democracy, to stimulate citizen participation in electoral communication, development and implementation of solutions; introduction of digital participation tools to participate in electoral process of residents (for example, distribution of digital communication services, including mobile application of personalized information "Informer for citizens", running on iOS and Android platforms in messengers, integrated with social networks, inquiries etc.). 
This is aimed at achieving the expected results, including increasing level of digital participation, initiative and involvement of citizens, civil society institutions, businesses at local level in managing the decision-making process, increasing their transparency and accountability democratic institutions; improving response of the subjects of power to the requests of citizens; introduction of new and increasing the number of used tools in digital democracy at the local level; increasing the level of public confidence in the subjects of power (Kerivni pryntsypy shchodo hromads'koyi uchasti u protsesi pryynyattya politychnykh rishen: rekomendatsiyi, pryynyati na 1295-tomu zasidanni zastupnykiv Ministriv Komitetu Ministriv Rady Yevropy vid 27 veresnya 2017 roku., 2017: URL).

Development of local and regional concepts of digital democracy makes it possible to analyze current state of e-democracy and identify priority measures for particular region or locality. Formation of policy of digital participation in electoral process is a new approach. This approach helps to respond quickly to global challenges that exist in society, as well as to preserve individuality of the territory in accordance with peculiarities of democratic processes.

It is important to understand that policy-making regarding the use of digital democracy tools at the regional or local level requires consideration of existing level of democracy, trust in government institutions and willingness to cooperate.

\section{General recommendations for implementation of the resource-technological mechanism of electoral communication}

In order to establish the processes of digital democracy, we offer general recommendations for organization at the local level:

1. To form systematically a thorough organizational vertical of state policy in the field of digital democracy to outline a given vector of development, calculate the necessary resources, stimulate the use of related areas, involve stakeholders from different fields in the formation and implementation of digital democracy policy.

2. To stimulate the need for broad involvement of citizens in understanding main trends and directions of implementation of digital democracy, as well as in its implementation at both national and local levels.

3. When carrying out organizational measures in the field of digital democracy, take into account the state of democracy development and legislative changes related to this area, global technological trends and aspects of implementation in this area, given that technical process is faster than legislative changes.

4. Focus on implementation of state policy in the field of digital democracy on local governments and civil society representatives as key actors / triggers of modern transformational changes.

5. To form common standards and approaches to creation of digital democracy tools at all levels of government to ensure access of citizens to electoral process, to intensify their participation in it (Levchenko O., 2018: 72-73).

NGOs have already become rightful players in decision-making processes. With rapid development of digital technologies, structural changes in state institutions and constant demand for change from society, it is non-governmental organizations that have the opportunity of significant impact on mechanisms of interaction between the government and the citizens. Civil society takes a share of the responsibility for effective and sustainable development of the state.

The World Bank's 2015 World Development Report focuses on how people actually think and make decisions using data from a variety of studies, rather than simply making their 
own assumptions (Kastels M., 2007: 103). And already in the report of the World Bank on the change in the nature of work for 2019 (Karchevska O. V., 2012: 15), (World Development Report "The Changing Nature of Work") emphasizes that digital technologies allow companies to quickly increase or decrease the scale of their activities, blurring the boundaries of companies and challenging former production models. Moreover, this report became an example of transparency, as in the process of development it was published weekly online for public review and comment.

According to researcher S. Mendelssohn, digital age has upset the balance of power between the state and the citizens, making the issue of sovereignty more flexible (Datsiuk S., 2011: 34). It is noted that if state sovereignty and power are transformed, it will ensure not only the use of digital technologies, but also organic spread of demand for transparent government activities, public participation in political processes and public events. Citizens' participation in electoral processes is closely correlated with the principle of good governance, which leads to a higher level of transparency and accountability of institutions. It also improves quality of management decisions, as institutions receive information about various possible consequences that decisions might have. Otherwise, institutions might not have access to that data. In addition, one of the most important effects of civic participation is implementation of decisions that are made (Dubas O. P., 2010: 118).

When studying sustainable development of digital democracy, special attention should be paid to digital competencies of citizens and their desire to use these tools in electoral process. It is important to realize that both public authorities and civil society organizations working in this field, promoting tools of digital democracy need to understand the benefits to the final beneficiaries, the users.

Important issue is the problem of digital inequality. Together, these aspects can lead to dominance of digital minority over other users, which cannot be allowed in order to maintain representativeness of all target groups in decision-making and further implementation of decisions by public authorities.

It should be noted that there are few active citizens, even fewer are consciously active, and therefore, there is danger of domination of this part over other users of resources and participants in the processes. This is especially true in rural areas, certain social groups cannot be included. In this case, a "digital vacuum" is created, where all problems seem to be solved, but it does not solve the real problems of society, but only the problems of some citizens who use its goods and services, contributing to stratification of society, not its integration (Duz O., 2010: 234).

Part of the public or public authorities can promote the position of expecting the citizens themselves to want to use tools of digital democracy. However, this argument is not justified, as significant part of management processes affect the majority of citizens. Thus consequences of decisions made, will affect everyone, not only those who participated in the decision-making process. Exclusion of certain categories narrows the legitimacy of decisions made, provided the process was transparent and open.

Therefore, it is necessary to identify two possible options for development of digital tools in electoral processes. This is an approach that makes it mandatory to use tools, or to provide other methods of motivation to use the tools and methods.

And it is non-governmental institutions that can stimulate involvement of citizens in the electoral process through use of digital tools (Duz O., 2010: 234).

In fact, such systematic activities lead to gradual interaction between citizens and public authorities. It is important not only to carry out informational and educational activities, but 
also to systematically raise the issue of expanding the number of interested citizens, participating in the decision-making processes important for the settlement or the country in general.

Ukraine has already developed many effective and efficient software products aimed at improving lives of residents, but citizens themselves may not know about them, may not be able to use them, or the problems that developed product solves are irrelevant in this region or locality. We suggest using a mechanism within which non-governmental organizations stimulate implementation of digital democracy processes. In this case, civil society institutions can serve as a catalyst for implementation of digital democracy (Duz O., 2010: 234).

Authorities must develop tools of participation independently and directly interact with residents. The tools can be developed by NGOs themselves and aimed at interaction with authorities or with residents themselves, or at interaction between the government and citizens in general.

In order to optimize the process of digital democracy, it is proposed to activate institutions of civil society - one of the subjects of electoral process, to develop and make decisions to accelerate promotion of electronic elections and improve the quality of electoral communications by Internet resources.

Authorities can develop digital democracy tools together with representatives of CSO civil society institutions (CSOs).

CSOs may or may not be involved in digital democracy processes, but it is this aspect that affects both the cost of tools themselves and distribution of functions related to digital democracy.

CSOs fulfil four functions:

1. Development and design of digital democracy tools.

2. Educating residents on proper use of existing digital democracy tools.

3. Animation (constant involvement of citizens) in the use of tools.

4. Advocacy (promotion) of digital democracy tools.

The more CSOs are involved in the process of digital democracy, the faster they advance to electronic elections and the quality of electoral communications will improve (Velychko N. E., Levchenko O. V., Sakalosh S. YE., Yaskevych A. Y., 2018: URL).

This is why it is extremely important to create mechanism and conditions for CSOs to take part of the responsibility for functioning of electoral communication through digital democracy. It is also worth noting that motivation to use these tools should be developed. After all, even with effective electoral communication and cooperation between authorities and non-governmental organizations, there is an important aspect of actual involvement of citizens in electoral process, to facilitate their needs of using such tools.

\section{Conclusion}

If we consider digital democracy in the context of political changes taking place in Ukraine, decentralization processes can be a stimulus and catalyst for its implementation. It is public organizations that have sufficient resources and capacity to facilitate dialogue, to participate in systemic changes of citizens' involvement in the electronic election process.

Systematic approach to formation of digital democracy processes to involve citizens in the electoral process with participation of CSOs promotes proper communication between government and community.

It is noted that for digital democracy processes to be effective there is a need to cover life cycle of decision-making processes from initiating the problem of involving citizens into 
electoral process to joint implementation of their chosen decision and, if necessary, choosing additional measures to correct or change the situation.

In order to accelerate promotion of electronic elections, it is suggested to use resource-technological mechanism by involving civil society institutions into cooperation with authorities based on participation in implementation of Internet electoral communications, which will improve the quality of resources for electoral process, development of tools for digital democracy in Ukraine Velychko N. E., Levchenko O. V., Sakalosh S. YE., Yaskevych A. Y., 2018: URL).

It is also noted that participation of CSOs in implementation of information and communication support of electoral processes based on the principles of participation affects the cost of resource-technological mechanism and increases efficiency of distribution of functions between the subjects of digital democracy.

\section{References}

Buchyn M. (2015) Osoblyvosti dotrymannia demokratychnykh pryntsypiv vyboriv pid chas pozacherhovykh prezydentskykh ta parlamentskykh vyboriv 2014 r. v Ukraini [Peculiarities of observance of democratic principles of elections during the early presidential and parliamentary elections of 2014 in Ukraine], vol. 27, pp. 48-54. [in Ukrainian].

Vyryn F. (2009) Ynternet-marketynh. Polnyi sbornyk praktycheskykh ynstrumentov [Internet marketing. Complete collection of practical tools] Moskow: Эskmo. [in Russian]

Datsiuk S. (2017) Intelektualna polityka [Intellectual policy]. Retrieved from: http:// www.uis.kiev.ua/ _ xyz/1_intellectual\%20policy.htm [in Ukrainian]

Dubas O. P. (2011) Elektronna demokratiia: sutnist i perspektyvy rozvytku v Ukraini [Electronic democracy: essence and prospects of development in Ukraine]. Visnyk Derzhavnoi akademii kerivnykh kadriv kultury i mystetstv: Kyjiv: Milenium, no. 1, pp. 187-190. [in Ukrainian] Duz O. V. (2010) Informatsiino-komunikatsiini tekhnolohii u vitchyznianykh elektoralnykh protsesakh [Information and communication technologies in domestic electoral processes]. Luhansk. [in Ukrainian]

Karpenko O., Levchenko O., Sakalosh S. (2019) Partysypatyvni transformatsii na mistsevomu rivni: elektronna ta tsyfrova demokratiia. [Participatory transformations at the local level: electronic and digital democracy]. Aktualni problemy derzhavnoho upravlinnia. Odesa, vol. 77, no. 1.124 p. [in Ukrainian]

Karchevska O. V. (2012) Rol politychnoi komunikatsii v elektoralnomu protsesi: teoretyko-metodolohichnyi analiz [The role of political communication in the electoral process: theoretical and methodological analysis Political science notes]. Politolohichni zapysky. Kyjiv: vol. 6, pp. 6-19. Retrieved from: http://nbuv.gov.ua/UJRN/Polzap_2012_6_19 [in Ukrainian]

Kastels M. (2007) Internet-halaktyka. Mirkuvannia shchodo Internetu, biznesu i suspilstva [Internet galaxy. Reflections on the Internet, business and society]. Moskow: "Vydavnytstvo "Vakler". [in Russian]

Kerivni pryntsypy shchodo hromads'koyi uchasti u protsesi pryynyattya politychnykh rishen: rekomendatsiyi, pryynyati na 1295-tomu zasidanni zastupnykiv Ministriv Komitetu Ministriv Rady Yevropy vid 27 veresnya 2017 roku (2017) [Guidelines for public participation in the political decision-making process: recommendations adopted at the 1295th meeting of the Deputy Ministers of the Committee of Ministers of the Council of Europe of 27 September 2017$].$ Retrieved from: https://rm.coe.int/guidelines-on-civil-participation-in-political-decision-making/168076e135 [in Ukrainian] 
Kuibida V. S. (2028) Tsyfrove vriaduvannia v Ukraini: bazovi definitsii poniatiino-katehorialnoho aparatu. [Digital governance in Ukraine: basic definitions of the conceptual and categorical apparatus]. Visnyk NADU pry Prezydentovi Ukrainy. Seriia “Derzhavne upravlinnia”. Retrieved from: http://visnyk.academy.gov.ua/pages/dop/77/files/07 ad5d26-4de5-410e-aflf5b7143c7d69c.pdf [in Ukrainian]

Levchenko O. (2018) Prykladni aspekty realizatsiyi polityky elektronnoyi demokratiyi v Ukrayini: problematyka informatsiynoho vyklyuchennya [Applied aspects of the implementation of e-democracy policy in Ukraine: issues of information exclusion]. Aktualni problemy derzhavnoho upravlinnya: Odesa, vol. 73, no. 1, pp. 73-76. [in Ukrainian]

Velychko N. E., Levchenko O. V., Sakalosh S. YE., Yaskevych A. Y. (2018) Monitorynh vprovadzhennya instrumentiv elektronnoho uryaduvannya $v$ orhanakh mistsevoho samovryaduvannya naybil'shykh mist Ukrayiny [Monitoring the implementation of e-government tools in local self-government bodies of the largest cities of Ukraine]. Hromadska orhanizatsiya "Podilska. Retrieved from: http://edemlab.org/assets/files/monitoring_2018_100-cities.pdf [in Ukrainian]

Rozporyadzhennya Kabinetu Ministriv Ukrayiny vid 17 sichnya 2018 r. № 67-r Pro skhvalennya Kontseptsiyi rozvytku tsyfrovoyi ekonomiky ta suspil'stva Ukrayiny na 2018-2020 roky ta zatverdzhennya planu zakhodiv shchodo yiyi realizatsiyi. [Order of the Cabinet of Ministers of Ukraine of January 17, 2018 № 67-r On approval of the Concept of development of the digital economy and society of Ukraine for 2018-2020 and approval of the action plan for its implementation]. 2018. Retrieved from: https: //zakon. rada. gov. ua/laws/show/67-2018-\%D1\%80 [in Ukrainian]

Chala N.D. (2018) Industriia 4.0: nova ekonomichna polityka Ukrainy. [Industry 4.0: Ukraine's new economic policy. Public administration of the XXI century: world practices and national perspectives]. Publichne upravlinnia XXI stolittia: svitovi praktyky ta natsionalni perspektyvy : zb. tez XVIII Mizhnar. nauk, konhresu, 26 kvitnia 2018 r. Kharkiv : Vyd-vo "Mahistr", pp. 405-407. [in Ukrainian]

Adams M., Banerjee A., Bayamlioglu E. (2017) Digital Democracy in a Globalized World / Elgar Law, Technology and Society series. Retrieved from: https://www.e-elgar.com/shop/digital-democracy-in-a-globalized-world

Retrieved from: https://rm.coe.int/guidelines-on-civil-participation-in-political-decision-making/168076e135 [Brazylyia]

Jakdojade Warszawa: digital service in Poland. Retrieved from: https://jakdojade.pl [Poland] 